\title{
DERI KANSERI HASTALARININ SERUM OKSIDATIF STRES PARAMETRELERININ DEĞERLENDIRILMESI
}

\section{Evaluation of Serum Oxidative Stress Parameters of Skin Cancer Patients}

\author{
İbrahim Halil YAVUZ ${ }^{1}$, Göknur ÖZAYDIN YAVUZ ${ }^{1}$, Serap GÜNEŞ BILGiLi' ${ }^{1}$, Halit DEMIR², \\ Canan DEMiR ${ }^{3}$
}

\section{ÖZET}

${ }^{1}$ Yüzüncü Yıl Üniversitesi Tıp Fakültesi,

Dermatoloji Anabilim Dalı, Van

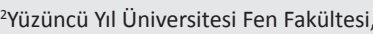
Kimya Bölümü, Van

${ }^{3}$ Yüzüncü Yıl Üniversitesi Sağlık Hizmetleri Meslek Yüksekokulu, Van

Ibrahim Halil YAVUZ, Dr. Öğr. Üyesi Göknur ÖZAYDIN YAVUZ, Dr. Öğr. Üy. Serap GÜNEŞ BiLGILi, Prof. Dr. Halit DEMIR, Prof. Dr. Canan DEMiR, Öğr. Gör.

iletişim:

Dr. Öğr. Üyesi Ibrahim Halil YAVUZ Yüzüncü Yıl Üniversitesi Tıp Fakültesi, Dermatoloji Servisi, 65300 Van Tel: 0(505) 4753361 e-mail:

ihalilyavuz@gmail.com

Geliş tarihi/Received: 08.08.2018 Kabul tarihi/Accepted: 23.10 .2018 DOI: $10.16919 /$ bozoktip.452100

Bozok Tip Derg 2018;8(4):127-133 Bozok Med J 2018;8(4):127-133
Giriş ve amaç: Deri kanserleri en sık görülen kanserlerden biridir. Bu kanserler non melanom ve melanom olarak genellikle iki grup altında incelenir ve çoğu nonmelanomadır. Deri kanserlerinin insidansı ve mortalite oranları tüm dünyada giderek artmaktadır. Bu çalışmada hücre içi antioksidanlar olan superoksit dismutaz (SOD), katalaz (CAT), redükte glutatyon (GSH), glutatyon redüktaz (GR), glutatyon peroksidaz (GPx) gibi moleküller ile oksidatif stres belirteci olan malondialdehit (MDA) değerlerini deri kanseri hastalarında incelemek istedik.

Materyal ve metod: Prospektif çalışma modifiye edilen Dünya Helsinki Deklarasyonu'na göre uygulandı. Bu çalışma üniversite hastanesinin dermatoloji departmanında yapıldı. Çalışmaya 30 deri kanseri hastası ve 30 sağlıklı gönüllü alındı. Çalışmaya katılanların serumlarında hücre içi antioksidantlar ve malondialdehit seviyeleri değerlendirildi

Bulgular: Çalışma 33 erkek (\%55), 27 kadın (\%45) olmak üzere toplam 60 kişi ile gerçekleştirilmiştir. Çalışmaya katılan kişilerin hasta ve kontrol grubuna göre yaş ve cinsiyet değişkenleri karşılaştırılmış aralarında anlamlı farklılık saptanmamıştır ( $p>0.05)$. GPx, GR, GSH, SOD, MDA, CAT değerlerinin, hasta ve kontrol grup ortalamaları arasındaki fark istatistik olarak önemli bulunmuştur $(p<0.05)$.

Sonuç: Bu çalışma deri kanseri hastalarında antioksidan serum düzeylerinin azaldığını ve oksidatif stres belirteci olan MDA'nın yüksek olduğunu göstermiştir.

Anahtar Sözcükler: Deri kanseri; Superoksit dismutaz; Katalaz

\section{ABSTRACT}

Introduction and objectives: Skin cancers are one of the most common cancers. These cancers are usually examined under two groups as non-melanomas and melanomas, and most nonmelanomas are. The incidence and mortality rates of skin cancers are increasing all over the world. In this study, we want to investigated the intracellular antioxidants such as superoxide dismutase (SOD), catalase (CAT), reductase glutathione $(G S H)$, glutathione reductase (GR), glutathione peroxidase (GPx) and malondialdehyde (MDA) values, which are oxidative stress markers, in skin cancer patients

Material and method: The prospective study was carried out according to the modified World Helsinki Declaration. This study was done in the dermatology department of the university hospital. Thirty skin cancer patients and 30 healthy volunteers were included in the study. Intracellular antioxidants and levels of malondialdehyde were evaluated of participants in the study

Results: The study consisted of 33 men (55\%) and 27 women (45\%). There was no significant difference between the age and gender variables of the study participants according to the patient and control group ( $p>0.05$ ). The difference between GPx, GR, GSH, SOD, MDA, CAT values, patient and control group averages were statistically significant $(p<0.05)$.

Conclusion: This study has shown that antioxidant serum levels are decreased in skin cancer patients and MDA, an oxidative stress marker, is high.

Keywords: Skin cancer; Superoxide dismutase; Catalase

Bu çalışma Yüzüncüyıl Üniversitesi Bilimsel Araştırma Başkanlığı tarafindan, 2015-TF-B321 numaralı proje ile desteklenmiştir. 


\section{Giriş}

Deri kanserleri en sık görülen kanserlerden biridir. Bu kanserler non melanom ve melanom olarak genellikle iki grup altında incelenir ve çoğu nonmelanomadır (1). Deri kanserlerinin insidansı ve mortalite oranları tüm dünyada giderek artmaktadır. Bunun en önemli sebeplerinden biri stratosferik ozon kaybından ötürü, yeryüzüne ulaşan ultraviole radyasyon miktarının artmasıdır (2). Tanı koymak için son yıllarda dermatoskop çok önemli bir metod olmasına rağmen kesin tanı histopatolojik değerlendirme ile konulur (1).

Aerobik organizmalar enzimatik ve nonenzimatik kısımlarından oluşan antioksidan sistem ile oksijen toksisitesinden korunurlar. Reaktif oksijen türlerinin artması ve antioksidan defans sisteminin azalması oksidatif stres olarak tanımlanır (3). Kanser gelişimi başlangıç, hızlanma, progression, olmak üzere üç önemli evresi olan kompleks bir durumdur. Reaktif oksijen türlerinin karsinogenezin bütün bu üç evrede de olduğu gösterilmiştir $(4,5)$. Reaktif oksijen türleri özellikle DNA ve hızlı bölünen hücreleri etkileyerek mutasyonlara sebep olabilir (6). Bu mutasyonların sonucu olarak kanser gelişimi kolaylaşır. Antioksidan sistem hasar öncesi radikal oluşumunu önler, oksidatif hasarı onarır, hasara uğramış molekülleri temizler ve mutasyonları önler. Sonuçta karsinogenezi önleyebilir $(5,7)$. Deri kanseri ile antioksidan defans sistemi arasındaki bağlantıyı gösteren çalışma azdır ve çelişkili sonuçlar vardır.

Bu çalışmada hücre içi antioksidanlar olan superoksit dismutaz (SOD), katalaz (CAT), redükte glutatyon (GSH), glutatyon redüktaz (GR), glutatyon peroksidaz (GPx) gibi moleküller ile oksidatif stres belirteci olan malondialdehit (MDA) değerlerini deri kanseri hastalarında incelemek istedik.

\section{MATERYAL-METOD}

Bu prospektif çalışma modifiye edilen Dünya Helsinki Deklarasyonu'na göre uygulandı. Yüzüncüyı Üniversite hastanesi etik kurulunun , 02-06-2015 tarihli ve 91 sayı numaralı onayı alındıktan sonra çalışmaya başlandı. $\mathrm{Bu}$ çalışma üniversite hastanesinin dermatoloji departmanında yapıldı. Çalışmaya 30 deri kanseri hastası ve 30 sağlıklı gönüllü alındı. Hastaların tanısı klinik, patolojik ve immunhistokimyasal olarak konuldu.
Kontrol grubu deri kanseri olmayan, başka hastalıklar veya kozmetik işlemler yaptrrmak için başvuran veya rutin kontrol amacıyla gelen gönülülerden seçildi. Çalışmada dışlanma kriterleri; antioksidan ve vitamin desteği almış olması, sistemik hastalığı, ilaç kullanımı, alkol tüketimi, enfeksiyon hastalığı varlığıdır.

\section{Örneklerin alınması}

Kan örnekleri sabah brakial venden boş tüplere alındı. Örnekler 10 dakika 5000 rpm'de santrifüj edildi. Alınan serumlar incelenene kadar -80 derecede saklandı.

\section{Süperoksit dismutaz (SOD) tayini}

Süperoksid dismutaz tayin için Williams ve arkadaşlarının metodu kullanıldı. Meydana gelen absorbans değişimi 505 nm'de ölçülerek enzim aktivitesi hesaplandı. Her bir standardın konsantrasyonuna karşı, yüzde inhibisyonu ile çizilen eğriden enzim aktivitesi U/ m1 olarak bulundu (8).

\section{Katalaz (CAT) enzim aktivite ölçümü}

CAT enzim aktivitesi substrat olarak hidrojen peroksit kullanarak saptandı. Aebi ve arkadaşlarının yöntemi kullanıldı (9). CAT seviyesi ölçülmeden önce serum örnekleri, 7.4 pH'de, Tris ve $\mathrm{HCl}$ ile dilüe edildi. Sonra $2.5 \mathrm{~mL}$ alınan, bu substrat $(50 \mathrm{mmol} / \mathrm{L}$ Tris ve $\mathrm{HCl}$ oluşan) karıştırıldı. Enzimin absorbans değişimi 240 $n m$ 'de spectofotometre ile ölçüldü. Değerler $\mathrm{U} / \mathrm{m} 1$ olarak hesaplandı.

\section{Redükte glutatyon (GSH) tayini}

Indirgenmiş glutatyon $(\mathrm{GSH})$, eritrositte bulunan sülfidril gruplarının DTNB (5',5'-(2-ditiobis nitrobenzoik asit) ile reaksiyonu sonucu sarı rengin oluşumu ile ölçüldü. Ölçümler spektrofotometre' de 412 nm' de gerçekleştirildi (10).

\section{Glutatyon peroksidaz (GPx) aktivitesi tayini}

GPx tayini için Randox marka ticari kit kullanıldı. Deneyin prensibi Paglia ve Valentine metoduna dayanmaktadır. NADPH' nin azalmasına bağlı olarak 340 $n m^{\prime}$ de meydana gelen absorbans değişimi ölçülerek enzim aktivitesi hesaplandı. Değerler $U / L$ cinsinden hesaplanarak yapıldı (11). 


\section{Malondialdehit (MDA) düzeyi tayini}

Yağ asitlerinin, serbest radikallerle reaksiyonu sonucu oluşan peroksidasyon ürünlerinden malondialdehit, tiobarbutirik asit ile renkli forma girmesi sonucu ölçüldü (12). Bir tüp içine serumdan $200 \mu \mathrm{l}$ alındı. Üzerine $800 \mu$ fosfat tamponu ve $25 \mu$ Bütil hidroksi toluen çözeltisi ve $500 \mu \mathrm{l} \% 30^{\prime}$ luk trikloroasetik asit eklendi. Tüpler vortekste karıştrılarak 2 saat buzda tutuldu. Buradan $1 \mathrm{ml}^{\prime}$ si alınarak başka tüplere aktarıldı. Bunların üzerine $75 \mu \mathrm{l}$ EDTA, $25 \mu \mathrm{l}$ Tiobarbitürik asit eklendi. Tüpler vortekste karıştrıldı ve $15 \mathrm{dk}$ sıcak suya maruz bırakıldı. Sonra oda ısısına getirilerek $532 \mathrm{~nm}$ 'de spektrofotometrede absorbansları okundu. değerler $\mu \mathrm{mol} / \mathrm{L}$ olarak hesaplandı.

\section{İstatistik Analiz Raporu}

Verilerin analizinde SPSS versiyon 17.0 programından yararlanılmıştır. Değişkenlerin normal dağılıma uygunluğu histogram grafikleri ve Kolmogorov-Smirnov testi ile incelendi. Tanımlayıcı analizler sunulurken ortalama, standart sapma ve ortanca değerleri kullanılmıştır. Kategorik gözlerde karşılaştırılmalar yapııırken Pearson Ki Kare Testi kullanılmıştır. Normal dağılım göstermeyen (nonparametrik) değişkenler gruplar arasında değerlendirilirken Mann Whitney U Testi kullanılmıştr.

\section{BULGULAR}

Çalışma 33 erkek (\%55), 27 kadın (\%45) olmak üzere toplam 60 kişi ile gerçekleştirilmiştir. Çalışmaya katılan kişilerin ortalama yaşı $57.7 \pm 16.1^{\prime}$ dir. Çalışmaya katılan hastalarda tanılar incelendiğinde bazal hücreli kanser ( BHK) olanların oranı \%30 kaposi sarkom olanların oranı $\% 6.7$, melanom olanların oranı $\% 16.7$, merkel hücreli kanser olanların oranı \%3.3, mikozis fungoides olanların oranı \%26.7, skuamöz hücreli kanser (SHK) olanların oranı \%16.7'dir. Hastalık yerleşimi incelendiğinde, ekstremitede olanların oranı \%33.3, vücutta olanların oranı $\% 16.7$, yüzde olanların oranı $\% 50.0$ 'dır. Aile hikayesi varlığı olanların oranı \%20.0, ortalama hastalık başlama yaşı $49.4 \pm 18.7$, ortalama hastalık süresi

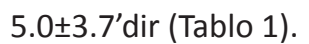

Çalışmaya katılan kişilerin hasta ve kontrol grubuna göre yaş ve cinsiyet değişkenleri karşılaştırılmış aralarında anlamlı farklılık saptanmamıştır ( $>>0.05$ ) (Tablo 2 ).
Tablo 1. Çalışmaya katılan kişilerin demografik özelliklerinin ve hastalık öyküsünün incelenmesi

\begin{tabular}{|c|c|c|c|}
\hline & & $\mathrm{n}$ & $\%$ \\
\hline \multirow[t]{2}{*}{ Cinsiyet } & Erkek & 33 & 55 \\
\hline & Kadın & 27 & 45 \\
\hline \multicolumn{2}{|l|}{ Yaş* } & $57.7 \pm 16.1$ & 63 \\
\hline & Bazal hücreli kanser & 9 & 30 \\
\hline & Kaposi sarkom & 2 & 6.7 \\
\hline & Melanom & 5 & 16.7 \\
\hline & $\begin{array}{l}\text { Merkel hücreli } \\
\text { kanser }\end{array}$ & 1 & 3.3 \\
\hline & Mikozis fungoides & 8 & 26.7 \\
\hline & $\begin{array}{l}\text { Skuamöz hücreli } \\
\text { kanser }\end{array}$ & 5 & 16.7 \\
\hline \multirow[t]{3}{*}{ Yerleşimi } & Yüz & 15 & 50 \\
\hline & Ekstremite & 10 & 33.3 \\
\hline & Vücut & 5 & 16.7 \\
\hline \multirow[t]{2}{*}{ Aile hikâyesi } & Yok & 24 & 80 \\
\hline & Var & 6 & 20 \\
\hline \multicolumn{2}{|l|}{ Başlama yaşı* } & $49.4 \pm 18.7$ & 48.5 \\
\hline \multicolumn{2}{|c|}{ Hastalık süresi* } & $5 \pm 3.7$ & 4 \\
\hline \multicolumn{4}{|c|}{$\begin{array}{l}\text { *Ölçümsel verilerde } n \text { yerine ortalama } \pm \mathrm{SS}, \% \text { değeri yerinede } \\
\text { medyan değerleri sunulmaktadır. }\end{array}$} \\
\hline
\end{tabular}

Tablo 2. Hasta ve kontrol grubuna göre cinsiyet ve yaş değişkenlerinin karşılaştrılıması

\begin{tabular}{|c|c|c|c|c|c|c|}
\hline & \multicolumn{5}{|c|}{ Grup } & \multirow[b]{2}{*}{$p$} \\
\hline & & \multicolumn{2}{|c|}{ Hasta } & \multicolumn{2}{|c|}{ Kontrol } & \\
\hline & & $\mathrm{n}$ & $\%$ & $n$ & $\%$ & \multirow{2}{*}{$0.795^{\mathrm{a}}$} \\
\hline \multirow[t]{2}{*}{ Cinsiyet } & Erkek & 17 & 56.7 & 16 & 53.3 & \\
\hline & Kadın & 13 & 43.3 & 14 & 46.7 & \multirow{2}{*}{$0.293^{b}$} \\
\hline \multicolumn{2}{|l|}{ Yaş* } & 53.5 & $40-70$ & 65 & $55-68$ & \\
\hline
\end{tabular}


yerine ortanca, \% değeri yerine de persantil (25-75) değerleri sunulmaktadır.

GPx, GR, GSH, SOD, MDA, CAT için tanımlayıcı istatistikler ve karşılaştırma sonuçları Tablo 3 'de verilmiştir. Tablo 3 incelendiğinde hasta ve kontrol grup ortalamaları arasındaki fark istatistik olarak önemli bulunmuştur $(p<0.05)$. 
Tablo 3. Tanımlayıcı istatistikler ve karşılaştırma sonuçları

\begin{tabular}{|l|l|l|c|l|}
\hline \multicolumn{2}{|c|}{ Grup } & $n$ & Ortalama \pm Std. Sapma & $p$ \\
\hline GPx & Hasta & 30 & $0.0573 \pm 0.0436$ & 0.001 \\
\hline$(U / m 1)$ & Kontrol & 30 & $0.5104 \pm 0.1302$ & \\
\hline GR & Hasta & 30 & $0.0929 \pm 0.0543$ & 0.001 \\
\hline$(U / m 1)$ & Kontrol & 30 & $0.5477 \pm 0.1447$ & \\
\hline GSH & Hasta & 30 & $0.0150 \pm 0.0069$ & 0.001 \\
\hline$(U / m 1)$ & Kontrol & 30 & $0.0606 \pm 0.0204$ & \\
\hline SOD & Hasta & 30 & $3.4464 \pm 1.5157$ & 0.001 \\
\hline$(U / m 1)$ & Kontrol & 30 & $8.3320 \pm 0.6149$ & \\
\hline MDA & Hasta & 30 & $1.5262 \pm 0.1822$ & 0.001 \\
\hline$(\mu \mathrm{mol} / \mathrm{L})$ & Kontrol & 30 & $0.7257 \pm 0.1037$ & \\
\hline CAT & Hasta & 30 & $0.0788 \pm 0.0116$ & 0.001 \\
\hline$(U / m 1)$ & Kontrol & 30 & $0.3693 \pm 0.1270$ & \\
\hline
\end{tabular}

\section{TARTIŞMA}

Bu çalışma deri kanseri hastalarında hücre içi antioksidantların seviyesinin düşük olduğunu ve lipit peroksidasyon ürünü olan MDA seviyesinin yüksek olduğunu göstermiştir. Reaktif oksijen türlerine karşı primer antioksidan enzim SOD'dır (13). Bazı çalışmalarda SOD'ın bazı formlarının kanser hücrelerinde aktivitesinin azaldığı gösterilmiştir. SOD’ın kanserin progresyonunu düzeltebileceği ve kanser tedavisi için yeni bir hedef ajan olarak kullanılabileceği belirtilmiştir. Ayrıca SOD'ın bazı hayvan modellerinde kanser önleyici etkisinin görülmesi gelecek için umut vaadeden bir molekül olarak görülmektedir (14). Darwish ve arkadaşlarının yaptığı çalışmada lenfomalı hastalarda SOD seviyelerinin tedavi öncesi ve sonrası azalmış olduğu saptanmıştı (15). Sander ve arkadaşlarının yaptığı çalışmada melanoma dokusunda SOD seviyesini yüksek saptamış, nonmelanoma deri kanserleri olan SHK ve BHK'da SOD seviyelerini düşük saptamıştır. Nonmelenoma deri kanserlerinde azalmış antioksidan sistemin karsinogenez ve mutasyonlara sebep olacağını buna karşın melanoma hücrelerinde metastazı artıracağını belirtmişlerdir (16). Mosad ve arkadaşlarının yaptığı çalışmada ise SOD değerleri akut lenfositik lösemi, Hodgin lenfoma (HL) hastalığında artmış olmasına rağmen Nonhodgkin lenfoma (NHL) hastalarında değişmemiştir. Fakat NHL hastalarında tedavi öncesi ve sonrası değerlerde kontrole göre arţş saptanmıştı. Sonuçta tümör hücreleri tarafindan üretilen serbest oksijen radikalleri malign lenfomalarda antioksidan enzim sistem aktivasyonunu değiştirir (17). Çalışmamızda SOD değerleri kanserli hastalarda düşüktü. Darwish ve arkadaşlarının yaptığı çalışmayı desteklemektedir. Bu ise deri tümörlerinde SOD değerlerinin etkilendiğini gösterebilir.

CAT enzimi reaktif oksijen ve reaktif nitrojen türlerine karşı önemli kilit bir enzimdir. Özellikle tümörlerde önemli oranda değiştiği bildirilmiştir. Aslında ilk keşfedilen ve en iyi bilinen antioksidan enzim olmasına rağmen tam mekanizması açıklanamamıştı (18). Bazı otörler kanser hücrelerinde CAT ekspresyonunun arttı̆ını ifade etmişlerdir, diğer çalışmalarda ise CAT aktivitesinin azalmış olduğu gösterilmiştir. Mosad ve arkadaşları CAT seviyelerinin NHL'ı hastalarda arttğını göstermişlerdir (17). Jayasree ve arkadaşlarının yaptığı çalışmada lenfomalı doğan fareler ile kontrol grubu arasında CAT enzim seviyelerinde belirgin bir azalma saptamışlardı ve bunun sonucunda reaktif oksijen seviyeleri ile ilişkili olduğunu belirtmişlerdir (19). Sander ve arkadaşlarının yaptığı çalışmada SHK'da tümör dokusunda CAT enzim seviyesinin yüksek olduğunu göstermişlerdir (16). Shen ve arakadaşlarının yaptı̆̆ı metaanaliz çalışmasında CAT gen polimorfizminin kanser için önemli bir risk faktörü olacağını belirtmişlerdir. Sebep olarak oksidatif strese kanser hücrelerinin daha hassas olacağı öne sürülmüştür (20). Bizde çalışmamızda CAT serum seviyesinin düşük saptadık. Bu da diğer çalışmalar ile uyumlu idi.

Glutatyon antioksidan defans sistemini sürdürmek ve reaktif oksijen türlerini temizlemek için gereklidir. Ayrıca DNA ve protein sentezi, enzim aktivitesi, gen ekspresyonunda rol oynar. Glutatyon sisteminin dengesizliği kanser ve onun progresyonunda önemli role sahiptir. Malign hücrelerde yükselmiş glutatyon seviyeleri, tümör büyümesi ve proliferatif yanıtla ilişkilidir. ilaveten tümör hücrelerinin oksidatif strese rezistansına sebep olmaktadır. Sonuçta bu özellik tümör hücrelerini kemoterapiye daha dirençli olmasını sağlamaktadır (21). Ghalaut ve arkadaşlarının yaptı̆̆ çalışmada akut lösemili hastalarda lenfosit glutatyon seviyelerinin kontrolden daha yüksek 
olduğunu bildirmişler ve sebebinin oksidatif stresle ilgili olabileceğini belirtmişlerdir (22). Navarov ve arkadaşlarının yaptı̆ı çalışmada tümörlü hastalarda glutatyon seviyesi yüksekti (23). Younus ve arkadaşlarının yaptığı çalışmada lenfomalı hastalarda GSH düzeyini düşük bulmuşlardır (14). Şu anki çalışmada deri kanserlerinde glutatyon seviyeleri Younus ve ark yaptığı çalışmaya benzer olarak düşüktü. Fakat Ghalaut ve arkadaşları ile Navarov ve arkadaşlarını çalışması ile çelişmektedir.

GPx'ın temel biyolojik rolü oksidatif stresten organizmayı korumaktır. Birkaç tümörde seviyesinin değiştiği rapor edilmiştir. Ayrıca tümör gelişimini inhibe ettiği gösterilmiştir (24). Jayashree ve arkadaşlarının yaptığı çalışmada lenfomalı doğan farelerde normal farelerle karşılaştrıldığı zaman GPx düşük olarak saptanmıştır (19). Lu ve ark yaptı̆̆ı çalışmada deri kanserli farelerde GPx seviyesinin arttğını göstermişlerdir (25). Walshe ve ark yaptı̆̆ı çalışmada GPx eksikliğinin ve UV varlığının deri skuamöz karsinom yaptığını göstermişlerdir (26). Çalışmamızda da GPx düşük saptanmıştr. Bu ise GPx'ın deri kanserini önlemede önemli rolü olabilir.

GR, glutatyonun rejenerasyonunda görevli olan homodimerik enzimdir. Ayn zamanda selenyum metabolizmasın da önemlidir (27). Navarro ve arkadaşlarının yaptı̆ı̆ı çalışmada tümörlü doğan fareler kontrol grubu ile karşılaştııldığında GR enziminde fark saptanmamıştır (23). Tisdale ve arkadaşlarının yaptığı çalışmada GR seviyeleri solid tümörlü hastalarda yüksek saptanmıştır (28). Çalışmamızda deri kanserli hastalarda GR seviyesi literatür ile uyumlu şekilde düşük saptandı.

Lipid peroksidazın son ürünü olan MDA oksidatif stresin en önemli göstergelerinden biridir. MDA kokarsinojen olarak hareket edebilir. Yapılan çalışmalarda bazı kanserlerde seviyelerinin arttğı gösterilmiştir (29). Morabito ve ark yaptiğı çalışmada HL hastalarında serum MDA seviyeleri kontrol grubuna göre yüksek saptanmıştır ve sonuçta lipid peroksidasyon ürünlerinin HL'de bir faktör olacağını belirtmişlerdir (30). Kaya ve arkadaşlarının yaptığı çalışmada HL hastalarda MDA seviyeleri tedaviden sonra önemli derecede azaldığı görülmüştür (31). Güven ve ark yaptı̆ı çalışmada HL'de
MDA seviyeleri yüksek saptanmıştır (32). Sander ve arkadaşlarının yapttğı çalışmada melanom ve SHK'li vakalarda MDA seviyelerinin attğı gösterilmiştir (16). Bu çalışma da Sander ve arkadaşlarının yaptığı çalışmayı desteklemektedir. Bu ise deri kanserlerinde MDA'nın önemli bir parametre olduğunu gösterebilir. Czajkowski ve arkadaşlarının yaptığı çalışmada deri kanseri olan melanom hastalarının, cerrahi önce ve sonrası, CAT ve GPx değerleri incelenmiş ve sonuçta GPx artmış olmasına rağmen bunların melanomanın prognozunda ve gelişiminde önemli olmadığını belirtmişlerdir (33). Çalışmamız bu çalışmadan farklı biçimde, bu değerlerin deri kanseri hastalarında önemli olduğunu göstermektedir.

Han ve arkadaşlarının yaptı̆̆ çalışmada deri kanserleri olan melanom, SHK ve BHK ile SOD gene mutasyonu ilişki saptamamışlardır (34). Çalışmamızda gen incelenmemesine rağmen, SOD değerlerinde değişiklik saptanmıştr

Lu ve arkadaşlarının yaptığı çalışmada SOD ve GPx aşırı eksprese eden farelerde, deri kanseri insidansında artma olduğunu belirtmişlerdir (35). Çalışmamızda değerler serumda incelendi. Doku düzeyinde değerlendirilmedi. Doku düzeyinde farklı sonuçlar elde edebilirdik.

Pence ve arkadaşlarının yaptı̆̆ çalışmada epidermal karsinogenez maruziyeti sonrası fare derisinde GPX, SOD ve CAT değerlerinde bazı değişimler olmasına rağmen, deri karsinogenezinde antioksidanların etkilerinin tartş̧malı olduğunu belirtmişlerdir (36). Çalışmamız Pence ve arkadaşlarının çalışmasından farklı olarak, hücre içi antioksidanların deri kanserinde önemli olabileceği sonucunu göstermektedir.

lizawavearkadaşlarınınyaptı̆ı̆ı̧alışmada derikanserinin en önemli sebebi olan ulturaviole radyasyonda meydana gelen serbest oksijen radikallerinin temizlenmesinde ve bazı enzimlerin aktivitesinde SOD, CAT ve Gpx etkili olduğunu belirtmişlerdir (37). Çalışmamız lizawa ve arkadaşlarının yaptığı çalışmayı desteklemektedir Antioksidan tedavi ile tümör hastalarında tedavide başarılı sonuçlar alındığını gösteren çalışmalar mevcuttur. Lenfomalı hastalarda antioksidan tedavi ile SOD ve CAT seviyelerinin arttğı ve bunun da tedavide etkili olabileceğini göstermiştir. Fakat literatür incelendiğinde oksidatif stresin kanserlerde olumlu sonuçlarının olduğunu gösteren çalışmalar da vardır 
(4). Seifirad ve ark.'nın yaptığı çalışmada oksidatif stres ve inflamasyonun farzedildiği kadar zararlı olmadığını; bu sistemlerin insan vücudunun malignitelere karşı doğal savunma sistemi olduğunu; antioksidan tedavinin sağlık için faydadan çok zararlı olabileceğini; hatta aşırı antioksidan tedavinin immün sistemi bozup malignensi gelişimini tetikleyebileceğini belirtmişlerdir (38).

Çalışmamızın bazı sınırlılıkları mevcuttur. Birincisi çalışılan materyaller serumlarda incelenmiş olup tümörlü doku değerlendirilmemiştir. íkincisi tek merkezli ve nispeten hasta sayısının az olmasıdır.

Sonuçta bu çalışma deri kanseri hastalarında antioksidan serum düzeylerinin azaldığını ve oksidatif stres belirteci olan MDA'nın yüksek olduğunu göstermiştir. Bu konunun daha iyi anlaşıması için çok merkezli ve hasta sayısının yüksek olduğu çalışmalara intiyaç vardır.

\section{KAYNAKLAR}

1. Linares MA, Zakaria A, Nizran P. Skin Cancer. Prim Care. 2015;42(4):645-59.

2. Marks R. An overview of skin cancers. Incidence and causation. Cancer. 1995;15;75(2 Suppl):607-12.

3. Basel H, Kavak S, Demir H, Meral I, Ekim H, Bektas H. Effect of levosimendan injection on oxidative stress of rat myocardium. Toxicol Ind Health. 2013;29(5):435-40.

4. Sander CS, Chang H, Hamm F, Elsner P, Thiele JJ. Role of oxidative stress and the antioxidant network in cutaneous carcinogenesis. Int J Dermatol. 2004;43(5):326-35.

5. Kryston TB, Georgiev AB, Pissis P, Georgakilas AG. Role of oxidative stres and DNA damage in human carcinogenesis. Mutat Res. 2011;711(1-2):193-201.

6. Waris G, Ahsan H. Reactive oxygen species: role in the development of cancer and various chronic conditions. J Carcinog.

2006;5:14.

7. Sorg O. Oxidative stress: a theoretical model or a biological reality? C R Biol. 2004;327(7):649-62.

8. Williams, J.A., Wiener, G., Anderson, P.H., McMurray, C.H.,. Variation in the activities of glutathione peroxidase and superoxide dismutase and in the concentration of copper in the blood in various breed crosses of sheep. Research Veterinary Science. 1983; 34: 253-256

9. Aebi H. Catalase In: Packer L, editor.Methods in enzymology. Orlando: Academic Press; 1984. p. 105. 121-6.

10. Beutler, E., Duron, O., Kelly, B.M.,. Improved method for the determination of blood glutathione. J Lab Clin Med 1963;61: 882-90. 11. Paglia D.E., Valentine W.N.,.Studies on the quantitative and qualitative charaterization of erythrocyte glutathione peroxidase. J
Lab Clin Med 1967;70 (19) : 158-169.

12. Gutteridge, J.M.,.Lipit peroxidation and antioxidants as biomarkers of tissue damage. Clin Chem. 1995;41(12): 1819-1828.

13. Oberley L.W. Representetive of Polypeptid Structure of Bovine CuZnSOD. Superoxide Dismutase, 1982;1:28

14. Younus $\mathrm{H}$. Therapeutic potentials of superoxide dismutase. International Journal of Health Sciences. 2018;12(3):88-93.

15. Darwish, Hossam \& Toson, Elshahat \& Hatem, A \& T El Zanaty, Ghada \& A Abdel, Camelia. oxidative stress-Antioxidant status in Egyptian Lymphoma patients.. Nature and Science of Sleep. 2012;10:31-37

16. Sander çalışma Sander CS, Hamm F, Elsner P, Thiele JJ. Oxidative stress in malignant melanoma and non-melanoma skin cancer. Br J Dermatol. $2003 ; 148(5): 913-22$.

17. Abou-Seif MA, Rabia A, Nasr M. Antioxidant status, erythrocyte membrane lipid peroxidation and osmotic fragility in malignant Iymphoma patients. Clin Chem Lab Med. 2000;38(8):737-42.

18. Glorieux C, Calderon PB. Catalase, a remarkable enzyme: targeting the oldest antioxidant enzyme to find a new cancer treatment approach. Biol Chem. 2017;398(10):1095-1108.

19. Jayashree G, Kurup Muraleedhara G, Sudarslal S, Jacob VB. Antioxidant activity of Centella asiatica on lymphoma-bearing mice. Fitoterapia. $2003 ; 74(5): 431-4$.

20. Shen Y, Li D, Tian P, Shen K, Zhu J, Feng M, et al. The catalase C262T gene polymorphism and cancer risk: a systematic review and meta-analysis. Medicine (Baltimore) 2015 ;94:e679.

21. Corso CR, Acco A. Glutathione system in animal model of solid tumors: From regulation to therapeutic target. Crit Rev Oncol Hematol. 2018;128:43-57.

22. Singh Ghalaut V, Kharb S, Ghalaut PS, Rawal A. Lymphocyte glutathione levels in acute leukemia. Clin Chim Acta. 1999;285 (1-2):85-9.

23. Navarro J, Obrador E, Carretero J, Petschen I, Aviñó J, Perez P, et al. Changes in glutathione status and the antioxidant system in blood and in cancer cells associate with tumour growth in vivo. Free Radic Biol Med. 1999;26(3-4):410-8.

24. Jiao $Y$, Wang $Y$, Guo $S$, Wang G. Glutathione peroxidases as oncotargets Oncotarget 2017;8(45):80093-80102.

25. Lu YP, Lou YR, Yen P, Newmark HL, Mirochnitchenko OI, Inouye $M$, et al.Enhanced skin carcinogenesis in transgenic mice with high expression of glutathione peroxidase or both glutathione peroxidase and superoxide dismutase.Cancer Res. 1997;57(8):1468-74. 26. Walshe J, Serewko-Auret MM, Teakle N, Cameron S, Minto K, Smith $\mathrm{L}$, et al. Inactivation of glutathione peroxidase activity contributes to UV-induced squamous cell carcinoma formation. Cancer Res. 2007;67(10):4751-8.

27. Björkhem-Bergman L, Jönsson K, Eriksson LC, Olsson JM, Lehmann S, Paul C,Björnstedt M. Drug-resistant human lung cancer cells are more sensitive to selenium cytotoxicity. Effects on thioredoxin reductase and glutathione reductase. Biochem Pharmacol. 2002;63(10):1875-84.

28. Tisdale MJ, Mahmoud MB. Activities of free radical metabolizing enzymes in tumours. Br J Cancer 1983 Jun;47(6):809-12.

29. Pirincci N, Kaba M, Gecit I, Gunes M, Yuksel MB, Tanik S, et al. 
Serum prolidase activity, oxidative stress, and antioxidant enzyme levels in patients with renal cell carcinoma. Toxicol Ind Health. 2016;32:193e9

30. Morabito F, Cristani M, Saija A, Stelitano C, Callea V, Tomaino A, et al. Lipid peroxidation and protein oxidation in patients affected by Hodgkin's lymphoma. Mediators Inflamm. 2004;13(5-6):381-3. 31. Kaya E, Keskin L, Aydogdu I, Kuku I, Bayraktar N, Erkut MA. Oxidant/antioxidant parameters and their relationship with chemotherapy in Hodgkin's lymphoma. J Int Med Res. 2005;33(6):687-92. 32. Güven M, Oztürk B, Sayal A, Ozet A. Lipid peroxidation and antioxidant system in the blood of patients with Hodgkin's disease. Clin Biochem. 2000;33(3):209-12.

33. Czajkowski R, Czajkowska A, Drewa T, Olszewska D, Zegarski W, Piech J,et al. Activity of antioxidant enzymes in melanoma patients. Int J Dermatol. 2013;52(11):1454-6.

34. Han J, Colditz GA, Hunter DJ. Manganese superoxide dismutase polymorphism and risk of skin cancer (United States). Cancer Causes Control. 2007;18(1):79-89.

35. Lu, Yao-Ping, et al. "Enhanced skin carcinogenesis in transgenic mice with high expression of glutathione peroxidase or both glutathione peroxidase and superoxide dismutase." Cancer Research 1997;57(8): 1468-1474.

36. Pence, Barbara C., and Mark F. Naylor. "Effects of single-dose ultraviolet radiation on skin superoxide dismutase, catalase, and xanthine oxidase in hairless mice." Journal of investigative dermatology 1990; 95(2): 213-216.

37. lizawa, O., et al. "Long-term follow-up study of changes in lipid peroxide levels and the activity of superoxide dismutase, catalase and glutathione peroxidase in mouse skin after acute and chronic UV irradiation." Archives of dermatological research 1994; 286(1): 47-52.

38. Seifirad S, Ghaffari A, Amoli MM. The antioxidants dilemma: are they potentially immunosuppressants and carcinogens? Front Physiol. 2014;15:245. 